JURNAL LENSA PENDAS

Volume 5 Nomor 2 Tahun 2020, Hlm 1 - 7

Available online at http://jurnal.upmk.ac.id/index.php/lensapendas

\title{
Hubungan Antara Kecerdasan Emosional Dengan Hasil Belajar Kognitif Siswa Kelas IV Pada Semester I Di SDN 2 Cileuya
}

\author{
Evi Nuraeni ${ }^{1}$, Agatha Kristi Pramudika Sari ${ }^{2}$ \\ Pendidikan Guru Sekolah Dasar, STKIP Muhammadiyah Kuningan \\ pramudika_sari@upmk.ac.id
}

Info Artikel

\section{Sejarah Artikel:}

Diterima Bulan Januari, 2020

Dipublikasikan Bulan

Februari, 2020

Keywords:

kecerdasan

emosional, hasil

belajar kognitif

emotional intelligence, cognitive learning

outcomes

\section{Abstrak}

Penelitian ini merupakan penelitian kuantitatif dengan metode korelasi. Sampel yang digunakan dalam penelitian ini adalah siswa kelas IV SDN 2 Cileuya, semester I tahun pelajaran 2018/2019. Teknik pengumpulan data yang digunakan adalah angket dan studi dokumentasi.. Kecerdasan emosional siswa kelas IV SDN 2 Cileuya termasuk dalam kategori tinggi sebesar $80 \%$. Hal ini dilihat pada kriterium tinggi dengan jarak interval $68 \%-100 \%$. Hasil belajar kognitif siswa kelas IV pada semester I di SDN 2 Cileuya memperoleh nilai terendah 723 dengan rata-rata 72,3 nilai tertinggi sebesar 810 dengan rata-rata 81 dan memperoleh ratarata secara keseluruhan sebesar 2419,6 berada diatas nilai Kriteria Ketuntasan Minimal (KKM) yang telah ditetapkan sebesar 70 . Hasil perhitungan uji hipotesisi diperoleh $t_{\text {hitung }}$ $(3,136)>t_{\text {tabel }}(1,697)$ (taraf signifikansi 5\% dengan $\left.\mathrm{dk}=32-2=30\right)$ maka $_{\mathrm{o}}$ ditolak dan $\mathrm{H}_{\mathrm{i}}$ diterima, artinya terdapat hubungan antara kecerdasan emosional dengan hasil belajar kognitif siswa kelas IV pada semester I di SDN 2 Cileuya". Kesimpulan dalam penelitian ini adalah terdapat hubungan antara kecerdasan emosional dengan hasil belajar kognitif siswa kelas IV pada semester I di SDN 2 Cileuya.

\section{Abstract}

This research is a quantitative research with correlation method. The sample used in this study was fourth grade students of SDN 2 Cileuya, first semester of the 2018/2019 academic year. . Emotional intelligence of grade IV SDN 2 students is included in the high category of S0\%. This is seen in the high criteria with a distance interval of 68\% - 100\%. Cognitive learning outcomes of fourth grade students in the first semester at SDN 2 Cileuya obtained the lowest score of 723 with an average of 72.3 the highest score of S10 with an average S1 and obtaining an overall average of 2419.6 above the minimum completeness criteria (KKM) which has been set at 70. The results of the hypothesis test calculation are obtained from $(3,136)>$ table $(1,697)(5 \%$ significance level with $d k=32-230)$ then $\mathrm{Ha}$ is rejected and $\mathrm{Hi}$ is accepted, meaning there is a relationship between emotional intelligence and cognitive learning outcomes of fourth grade students in semester I at Cileuya SDN 2. "The conclusion in this study is that there is a relationship between emotional intelligence and cognitive learning outcomes of fourth grade students in the first semester at SDN Cileuya.

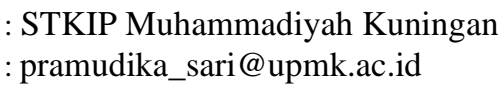




\section{Jurnal Lensa Pendas, Vol. 5 Nomor 2 Tahun 2020, HIm 1 - 7}

Evi Nuraeni ${ }^{1}$, Agatha Kristi Pramudika Sari ${ }^{2}$

\section{PENDAHULUAN}

Pendidikan yang diterapkan saat ini lebih mengutamakan siswa untuk belajar. Belajar menunjukkan adanya perubahan yang signifikan terhadap siswa yang sifatnya positif sehingga akan didapat keterampilan, kecakapan dan pengetahuan baru. Untuk mengetahui sampai seberapa jauh perubahan yang terjadi, perlu adanya penilaian. Begitu juga dengan yang terjadi pada seorang siswa yang mengikuti suatu pendidikan selalu diadakan penilaian dari hasil belajarnya. Pembelajaran yang diterapkan di Sekolah Dasar dalam Kurikulum 2013 saat ini berlandaskan pada Permendikbud Nomor 65 Tahun 2013 tentang. Standar Proses Pendidikan Dasar dan Menengah yang menyebutkan bahwa, "Sesuai dengan Standar Kompetensi Lulusan dan Standar Isi, maka prinsip pembelajaran yang digunakan dari pembelajaran parsial menuju pembelajaran terpadu." Kurikulum 2013 juga merupakan sebuah pembelajaran yang menekankan pada aspek kognitif, afektif, dan psikomotor. Oleh sebab itu, hasil belajar yang akan dicapai pada Kurikulum 2013 harus mencakup pada aspek kognitif, afektif dan psikomotor.

Menurut Ahmad Susanto (2013: 5) hasil belajar siswa adalah kemampuan yang diperoleh anak setelah melalui kegiatan belajar. Hasil belajar yang baik akan dihasilkan apabila tingkat pemahaman yang dimiliki siswa baik pula. Kemajuan hasil belajar siswa tidak saja diukur dari tingkat penguasaan ilmu pengetahuan (kognitif), tetapi juga sikap (afektif), dan keterampilan (psikomotor).

Menurut Kosasih dan Sumarna (2014: 173) kecerdasan dikelompokkan menjadi 3 (tiga), antara lain: kecerdasan emosional (EQ), kecerdasan intelektual (IQ) dan kecerdasan spiritual (SQ).

Proses belajar yang dilakukan disekolah sering ditemukan peserta didik yang tidak dapat meraih hasil belajar yang setara dengan kemampuan inteligensinya. Ada peserta didik yang mempunyai kemampuan inteligensi tinggi tetapi memperoleh prestasi belajar yang relatif rendah, dan ada pula yang sebaliknya. Hal ini terjadi karena taraf inteligensi bukan merupakan satu-satunya faktor yang menentukan keberhasilan seseorang, melainkan ada pula faktor lain yang mempengaruhi. Siswa yang memiliki kecerdasan intelektual saja belum cukup untuk mencapai hasil belajar yang maksimal, yang ideal adalah kecerdasan intelektual yang diiringi dengan kecerdasan emosional yang seimbang.

Fenomena lain yang kini muncul pada sebagian besar siswa di SDN 2 Cileuya adalah tingginya hasil belajar kognitif siswa khususnya di kelas IV. Hal ini, hasil belajar yang dicapai siswa cenderung tinggi. Banyak faktor yang menentukan tingginya hasil belajar kognitif siswa khususnya di kalangan Sekolah Dasar. Salah satunya adalah kemampuan intelektual dan kecerdasan emosional siswa bekerja secara seimbang. 
Jurnal Lensa Pendas, Vol. 5 Nomor 2 Tahun 2020, HIm 1 - 7

Evi Nuraeni ${ }^{1}$, Agatha Kristi Pramudika Sari ${ }^{2}$

Berdasarkan tingginya hasil belajar kognitif siswa kelas IV di SDN 2 Cileuya, maka peneliti tertarik untuk meneliti tentang ada atau tidaknya hubungan antara kecerdasan emosional dengan hasil belajar kognitif siswa sehingga dapat menghasilkan nilai yang tinggi pada hasil belajar kognitif siswa kelas IV.

Berdasarkan hal tersebut, penjelasan mengenai hubungan antara kecerdasan emosional dengan hasil belajar kognitif siswa sangat penting sebagai sumber pengetahuan guru dalam mengajar. Oleh karena itu, peneliti tertarik untuk melaksanakan penelitian dengan judul: "Hubungan

antara Kecerdasan Emosional dengan Hasil Belajar Kognitif Siswa Kelas IV pada Semester I di SDN 2 Cileuya".

\section{METODE PENELITIAN}

Mengacu pada perumusan masalah, maka penelitian ini menggunakan metode kuantitatif dengan jenis penelitian korelasional untuk menguji hubungan antara dua variabel. Sugiyono (2015: 14) menjelaskan bahwa metode penelitian kuantitatif dapat diartikan sebagai metode penelitian yang berlandaskan pada filsafat positivisme, digunakan untuk meneliti pada populasi atau sampel tertentu, teknik pengambilan sampel pada umumnya dilakukan secara random, pengumpulan data menggunkan instrumen penelitian, analisis data bersifat kuantitatif/statistik dengan tujuan untuk menguji hipotesis yang telah ditetapkan.

Arikunto (2013: 4) mendefinisikan penelitian korelasional sebagai penelitian yang dilakukan oleh peneliti untuk mengetahui tingkat hubungan antara dua variabel atau lebih, tanpa melakukan perubahan, tambahan atau manipulasi terhadap data yang sudah ada. Artinya tidak ada perlakuan terhadap variabel seperti halnya penelitian eksperimen.

Berdasarkan pendapat diatas, bahwa dalam setiap penelitian diperlukan adanya metode yang sesuai dengan tujuan penelitian yang akan dicapai. Oleh sebab itu, penelitian ini dilakukan dengan menggunakan metode korelasional, metode ini dilakukan untuk mengetahui ada atau tidaknya hubungan antara kecerdasan emosional dengan hasil belajar kognitif siswa kelas IV pada semester I di SDN 2 Cileuya.

Pada penelitian kuantitatif, analisis data merupakan kegiatan setelah data dari seluruh responden atau sumber data lain terkumpul. Sugiyono (2015: 335) menyatakan bahwa analisis data adalah kegiatan mengelompokkan data berdasarkan variabel dan jenis responden, penyajian data dalam tabel berdasarkan variabel dari seluruh responden, menyajikan data tiap variabel yang diteliti, melakukan perhitungan untuk menjawab masalah dan untuk menguji hipotesis yang diajukan. Teknik analisis data dalam penelitian ini digunakan untuk mengetahui sejauh mana hubungan 


\section{Jurnal Lensa Pendas, Vol. 5 Nomor 2 Tahun 2020, HIm 1 - 7}

Evi Nuraeni ${ }^{1}$, Agatha Kristi Pramudika Sari ${ }^{2}$

kecerdasan emosi dengan hasil belajar kognitif siswa kelas IV pada semester I di SDN 2 Cileuya. Pada penelitian ini analisis data dilakukan dengan bantuan aplikasi SPSS versi 21.

Uji normalitas digunakan untuk mengetahui normalitas data apakah data tersebut berdistribusi normal dengan menggunakan uji chi kuadrat.

Keterangan:

$X^{2}=$ chi-kuadrat hitung

$O_{i}=$ frekuensi hasil pengamatan (frekuensi observasi) ke-

$E_{i}=\quad$ frekuensi

yang diharapkan

(frekuensi ekspektasi) ke- $i$

Selanjutnya membandingkan $\mathrm{X}_{\text {hitung }}^{2}$ $\leq X_{\text {tabel }}^{2}$ artinya distribusi data normal, sedangkan jika $\mathrm{X}_{2 \text { hitung }} \geq \mathrm{X}_{2 \text { tabel }}$ artinya distribusi data tidak normal. Perhitungan uji normalitas dilakukan dengan menggunakan SPSS versi 21

Teknik pengumpulan data menurut Arikunto (2013: 126) adalah cara-cara yang dapat digunakan oleh peneliti untuk mengumpulkan data. Teknik pengumpulan data mengacu pada cara data yang diperlukan dalam penelitian dapat diperoleh. Kaitannya dengan hal tersebut, serta dengan melihat konsep analisis dari penelitian ini, maka teknik pengumpulan data yang digunakan

\section{HASIL PENELITIAN DAN PEMBAHASAN}

Menurut Daniel Goleman (2018:

45) kecerdasan emosional (emotional intelligence) adalah kemampuan untuk mengenali perasaan kita sendiri dan perasaan orang lain, kemampuan memotivasi diri sendiri, dan kemampuan mengelola emosi dengan baik pada diri sendiri dan dalam hubungan dengan orang lain. Kecerdasan emosional meliputi kesadaran diri, peraturan diri, motivasi, empati dan keterampilan sosial.

Goleman (Narni, 2018:37) menyatakan bahwa kecerdasan emosional perlu diajarkan di sekolahsekolah supaya anak-anak mempunyai peluang untuk keterampilan yang akan membantu menjadi lebih kebal terhadap depresi, gangguan pola makan, kekerasan, dan berbagai jebakan lain yang merugikan. Kecerdasan emosional adalah kemampuan mengidentifikasi, memberi label, mengungkapkan dan mengelola perasaan, mengendalikan dorongan hati, mengurangi stres dan menunda pemuasan

Berdasarkan hal tersebut dapat disimpulkan bahwa siswa yang memiliki kecerdasan emosional yang tinggi dapat bergaul dengan dengan baik, mampu mengontrol emosi dan keinginan, serta dapat dipastikan akan mendapatkan prestasi yang tinggi dibidang akademik.

Setelah peneliti melakukan

pengolahan data peneliti

peneliti memperoleh gambaran mengenai Kecerdasan Emosional Siswa dan Hasil Belajar Kognitif Siswa Kelas IV pada Semester I di SDN 2 Cileuya, sebagai berikut.

\section{Kecerdasan Emosional}

Siswa Kelas IV SDN 2 Cileuya

Berdasarkan hasil analisis deskripsi diperoleh gambaran variabel $X$ (kecerdasan emosional siswa) di SDN 2 Cileuya termasuk dalam kategori tinggi sebesar $80 \%$. Hal ini dilihat pada kriterium tinggi dengan jarak interval $68 \%-100 \%$. Berdasarkan persentase tersebut menunjukkan gambaran kecerdasan emosional siswa kelas IV SDN 2 Cileuya sudah baik. Kecerdasan emosional adalah bekal penting menyongsong siswa dalam meraih masa depan, karena seseorang akan lebih mudah dan berhasil menghadapi segala 


\section{Jurnal Lensa Pendas, Vol. 5 Nomor 2 Tahun 2020, HIm 1 - 7}

Evi Nuraeni ${ }^{1}$, Agatha Kristi Pramudika Sari ${ }^{2}$

macam tantangan kehidupan, termasuk tantangan untuk dapat berhasil secara akademis. Selain itu, perilaku siswa dalam proses belajar mengajar juga disasumsikan turut jelas mempengaruhi capaian hasil belajar kognitif siswa. Hakikatnya siswa yang memiliki kecerdasan intelektual saja belum cukup untuk mencapai hasil belajar yang maksimal, yang ideal adalah kecerdasan intelektual yang diiringi dengan kecerdasan emosional secara seimbang. Kunci dari kecerdasan emosional adalah suara hati. Suara hati inilah yang dicari oleh Steven Covey didalam bukunya "The Seven Habits" (Narni, 2018: 35). Ini yang seharusnya dijadikan sebagai pusat prinsip yang akan memberikan rasa aman, pedoman, daya dan kebijaksanaan. Tingkat kecerdasan emosional siswa sangat bergantung pada kemampuan memahami perasaan diri sendiri dan perasaan orang lain.

Berdasarkan hal tersebut dapat disimpulkan bahwa siswa yang memiliki kecerdasan emosional yang tinggi dapat bergaul dengan dengan baik, mampu mengontrol emosi dan keinginan, serta dapat dipastikan akan mendapatkan prestasi yang tinggi dibidang akademik.

2. Hasil Belajar Kognitif Siswa Kelas IV pada Semester I SDN 2 Cileuya Berdasarkan hasil analisis diperoleh gambaran bahwa hasil belajar kognitif siswa kelas IV pada semester I di SDN 2 Cileuya memperoleh nilai terendah 723 dengan rata-rata 72,3 nilai tertinggi sebesar 810 dengan rata-rata 81 dan memperoleh rata-rata secara keseluruhan sebesar 2419,6 berada diatas nilai Kriteria Ketuntasan Minimal (KKM) yang telah ditetapkan sebesar 70. Hal ini membuktikan bahwa hasil belajar kognitif siswa kelas IV pada semester I di SDN 2 Cileuya termasuk kategori tinggi atau baik. Tujuan pendidikan yang diterapkan saat ini diharapkan siswa mampu memperoleh hasil belajar yang baik dalam proses pembelajaran sehingga dapat mengembangkan kemampuan yang ada pada dirinya untuk memiliki kecerdasan, keterampilan, kekuatan spiritual keagamaan, dan pengendalian diri atau emosi.

Menurut Ahmad Susanto (2013: 5) hasil belajar siswa adalah kemampuan yang diperoleh anak setelah melalui kegiatan belajar. Hasil belajar yang baik akan dihasilkan apabila tingkat pemahaman yang dimiliki siswa baik pula.

Berdasarkan pendapat para ahli di atas, peneliti menyimpulkan bahwa hasil belajar adalah kemampuankemampuan yang dimiliki siswa setelah mengikuti kegiatan pembelajaran. Kemampuan tersebut meliputi ranah kognitif, afektif, dan psikomotor yang dapat diukur dengan evaluasi.

Menurut Nana Sudjana (2014: 22) berkenaan dengan hasil belajar intelektual yang terdiri dari

enam aspek, yakni pengetahuan atau ingatan, pemahaman, aplikasi, analisis, sintesis, dan evaluasi. Ranah kognitif berhubungan erat dengan kemampuan berpikir, termasuk kemampuan menghafal, memahami, mengaplikasikan, menganalisis,

menyintesis, dan kemampuan mengevaluasi.

Berdasarkan pendapat para ahli, dapat disimpulkan bahwa hasil belajar kognitif adalah hasil belajar yang mengutamakan kemampuan memahami ilmu pengetahuan secara intelektual, kemampuan menganalisis serta mengevaluasi yang ada pada setiap individu.

3. Hubungan antara Kecerdasan Emosional dengan Hasil Belajar Kognitif Siswa Kelas IV pada Semester I di SDN 2 Cileuya.

Berdasarkan perhitungan uji statistik menggunakan SPSS versi 21 dengan uji normalitas data variabel $\mathrm{X}$ (kecerdasan emosional siswa) diperoleh pada kolom signifikan (Asymp. Sig. (2-tailed)) adalah 0,899 berarti lebih besar dari 0,05 atau $0,899>0,05$ maka $\mathrm{H}_{0}$ diterima artinya berdistribusi normal. Sementara itu, untuk variabel Y (hasil belajar kognitif) pada kolom signifikan (Asymp. Sig. (2-tailed)) adalah 0,444 berarti lebih besar dari 0,05 atau 0,444>0,05 


\section{Jurnal Lensa Pendas, Vol. 5 Nomor 2 Tahun 2020, HIm 1 - 7}

Evi Nuraeni ${ }^{1}$, Agatha Kristi Pramudika Sari ${ }^{2}$

maka $\mathrm{H}_{0}$ diterima artinya berdistribusi normal. Hal ini berarti hipotesis yang menyatakan "Terdapat hubungan antara kecerdasan emosional dengan hasil belajar kognitif siswa kelas IV pada semester I di SDN 2 Cileuya" secara statistik dapat diterima.

Penelitian ini dapat disimpulkan bahwa adanya hubungan antara kecerdasan emosional dengan hasil belajar kognitif siswa. Penelitian ini dapat menjadi acuan untuk meningkatkan hasil belajar siswa terutama pada ranah kognitif. Hal ini diperkuat oleh penelitian yang telah dilakukan serta teori yang relevan.

\section{SIMPULAN}

Berdasarkan hasil pengolahan data dan pembahasan tendang hubungan antara kecerdasan emosional dengan hasil belajar kognitif siswa kelas IV pada semester I di SDN 2 Cileuya, maka peneliti menarik kesimpulan sebagai berikut: 1 . Kecerdasan emosional siswa kelas IV di SDN 2 Cileuya dengan kriteria rendah sebesar 31,25\% dengan jumlah frekuensi sebanyak 10 responden, kriteria sedang sebesar 31,25\% dengan jumlah frekuensi sebanyak 10 responden, dan kriteria tinggi sebesar 37,5\% dengan jumlah frekuensi sebanyak 12 responden. Secara komulatif kecerdasan emosional siswa kelas IV di SDN 2 Cileuya telah mencapai $80 \%$ dari kriteria yang telah ditetapkan. Hal ini termasuk pada kriterium tinggi dengan jarak interval 68\% - 100\%. Berdasarkan persantase tersebut menunjukkan bahwa kecerdasan emosional siswa kelas IV di SDN 2 Cileuya sudah baik. Hasil belajar kognitif siswa kelas IV pada semester I di SDN 2 Cileuya memperoleh nilai terendah sebesar 723 dengan rata-rata 72,3 dan nilai tertinggi sebesar 810 dengan ratarata 81 . Sementara itu, nilai rata-rata secara keseluruhan sebesar 2419,6 berada di atas nilai Kriteria Ketuntasan Minimal (KKM) yang telah ditetapkan sebesar 70. Hal ini membuktikan bahwa hasil belajar kognitif kelas IV pada semester I di SDN 2 Cileuya terbasuk kedalam kategori tinggi dan baik.

Berdasarkan hasil perhitungan uji hipotesis diatas diperoleh nilai $t_{\text {hitung }}=3,136$.
Kemudian untuk menentukan nilai tabel dengan jumlah sampel 32 diperoleh nilai $\mathrm{t}_{\text {tabel }}=1,697$ (taraf signifikansi 5\% dengan $\mathrm{dk}$ $=32-2=30$ ). Sehingga diketahui bahwa $\mathrm{t}_{\text {hitung }}=3,136$ lebih besar dari $\mathrm{t}_{\text {tabel }}=1,697$ atau $t_{\text {hitung }}=3,136>$ dari $t_{\text {tabel }}=1,697$, maka $\mathrm{H}_{\mathrm{o}}$ ditolak dan $\mathrm{H}_{\mathrm{i}}$ diterima. Hal ini berarti hipotesis yang menyatakan "Terdapat hubungan antara kecerdasan emosional dengan hasil belajar kognitif siswa kelas IV pada semester I di SDN 2 Cileuya" secara statistik dapat diterima.

\section{DAFTAR PUSTAKA (12PT)}

Arikunto, Suharsimi. (2013). Prosedur Penelitian. Jakarta: Rineka Cipta.

Kosasih, Nandang dan Dede Sumarna. (2014). Pembelajaran Quantum dan Optimalisasi Kecerdasan. Bandung: Alfabeta.

Narni. (2018). Mengembangkan Kecerdasan Emosional dan Spiritual Siswa.

Sudjana, Nana. (2014). Penilaian Hasil Proses Belajar Mengajar. Bandung: PT. Remaja Rosdakarya.

Sugiyono. (2015). Metode Penelitian Pendidikan. Bandung: Alfabeta.

Susanto, Ahmad. (2013). Teori Belajar dan Pembelajaran di Sekolah Dasar. Jakarta: Kencana Prenada Media Group. 